\title{
Effects of frozen storage on the proximate composition and formaldehyde content in some selected fish from three different sources of southern Bangladesh
}

\author{
MD. BOKTHIER RAHMAN ${ }^{1}$, MD. SAZEDUL HOQUE ${ }^{*}$, SUPRAKASH CHAKMA ${ }^{1}$, \\ SHAIDA AKTER ${ }^{2}$, S.M. OASIQUL AZAD ${ }^{1}$ AND MST. RUMA ${ }^{3}$ \\ ${ }^{1}$ Department of Fisheries Technology, Patuakhali Science and Technology University, Patuakhali 8602, Bangladesh \\ ${ }^{2}$ Department of Fisheries Management, Bangabandhu Sheikh Mujibur Rahman Agricultural University, \\ Gazipur 1706, Bangladesh.
}

${ }^{3}$ Department of Fisheries Management, Patuakhali Science and Technology University, Patuakhali 8602

*Email: sazedul.fst@pstu.ac.bd

\begin{abstract}
The study was conducted in aims to investigate the effects of frozen storage and cooking conditions on proximate compositions and formaldehyde content (FA) in some selected fish from three different sources in Bangladesh. Proximate composition in fresh and final frozen samples was determined by standard AOAC method and FA content in fresh, frozen stored, and cooked samples was determined by spectrophotometric method. Among the studied fishes, marine fish contained higher protein (except Rita), lipid, and ash followed by estuarine and culture fish samples. Protein, moisture and ash content decreased and lipid content increased significantly $(p<0.05)$ during frozen storage for all samples and sources. The FA was lower in cultured fish samples compared to that of the river and marine fish samples, both at fresh and end of frozen storage. At fresh condition, FA content in all samples ranged from 0.41 to $0.71 \mu \mathrm{g} / \mathrm{g}, 0.51$ to $0.89 \mu \mathrm{g} / \mathrm{g}$, and 0.73 to $1.69 \mu \mathrm{g} / \mathrm{g}$ which increased to 0.95 to $2.11 \mu \mathrm{g} / \mathrm{g}, 1.74$ to $1.95 \mu \mathrm{g} / \mathrm{g}$, and 3.22 to $5.20 \mu \mathrm{g} / \mathrm{g}$ at end of the storage period, respectively $(p<0.05)$. Further, FA content significantly decreased after cooking in all the fish samples $(p<0.05)$. However, irrespective of fish species and sources, the FA content was higher than WHO recommended value $(0.2 \mu \mathrm{g} / \mathrm{g})$. The study findings revealed that longer frozen storage of fish could be a public health concern to the consumers.
\end{abstract}

Keywords: Frozen storage, Proximate composition, Formaldehyde content, Spectrophotometric method

\section{Introduction}

Recent trends in global food production, preparation, processing and distribution are creating an increasing demand for food safety research to ensure safe food supply globally (Bianchi et al. 2007, Norliana et al. 2009, Hoque et al. 2016, Hoque et al. 2018). The supply of quality foods mainly interrupted by the different types of physical, chemical, and biological hazards present in food (Erondu and Anyanwu 2005, Bianchi et al. 2007, Ahmed et al. 2012, Chiou et al. 2015, Handford et al. 2016). Among the different chemical contaminants in food, great attention has been paid towards volatile toxic aldehydes like formaldehyde (FA) (Bianchi et al. 2007; Norliana et al. 2009, Zhang et al. 2015). In fish, FA could be accumulated naturally upon postmortem changes and during frozen storage from the enzymatic reduction of trimethylamine- $\mathrm{N}$ oxide (TMAO) to dimethylamine and FA (Sotelo 1995, Bianchi et al. 2007) as shown in Fig. 1.

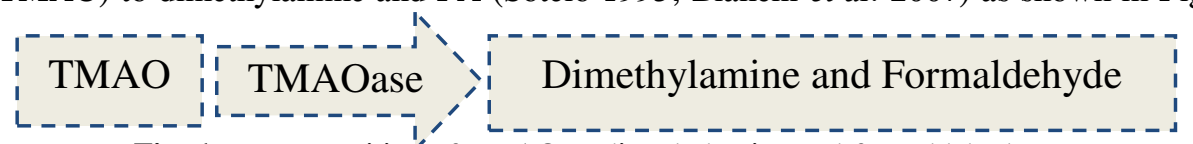

Fig. 1. Decomposition of TMAO to dimethylamine and formaldehyde. 
FA contents in fish vary from species to species, location, and other factors (Hoque et al. 2018). Marine fish contained higher TMAO contents indicating higher FA (Tsuda et al. 1988, Jiang et al. 2006) than freshwater fish. Fish frozen is a common scenario as it inhibits the microbial, enzymatic, and autolytic activity in fish lowering the body temperature thus allowing the fish to preserve for a period. But, during frozen storage leaching, drip loss, denaturation, and degradation of protein and other biochemical components caused lower food value (Benjakul et al. 2003, Emire and Gebremariam 2010). Also, the duration of frozen storage has a great impact to increase muscle FA content to a great extent (Sotelo et al. 1995, Bianchi et al. 2007, Zhang et al. 2015). Allow dose of FA can cause pain, vomiting, lethargy whereas a large doses a source of death for consumers (Zhang et al. 2015). Consumption of fish containing FA could increase the risk of cancer or uncontrolled cell growth on different parts of consumers like the stomach, lung, and also on the respiratory system through inhalation (Hoque et al. 2016).

Frozen storage condition and duration affects its proximate composition and FA formation, content, and food value in consequences on the health of the consumers. In Bangladesh, limited study has been conducted to see the effects of frozen storage on the proximate composition (Mazrouh 2015, Mahboob et al. 2019, Adel et al. 2019). However, no study conducted on the effects of frozen storage on the FA content in fish from different sources. Thus, addressing this problem, present study has been directed based on proximate composition and FA content in different fish from three sources of water bodies in the Southern Bangladesh and to reveal the changes of nutritional properties and FA content both in fresh, cooked and frozen storage condition.

\section{Materials and Methods}

Fish samples collection: Fish samples from three different sources i.e., PSTU fish culture pond (Pangas, Pangasius pangasius; Koi, Anabas testudineus and Catla, Gibelion catla; Paira river (Ramchos, Thryssa purava; Lalpoa, Otolithoides pama and Tulardadi, Sillaginopsis panijus) and Kuakata marine water (Rita, Rita rita; Sardine, Sardinella longiceps and Tuna, Sarda orientalis) were collected for proximate composition and FA determination in fresh and frozen storage (Walton, W2D-1H5, Bangladesh) condition.

Determination of proximate composition: Nutritional properties of fishes under the designation of moisture, protein, lipid, and ash content were determined by AOAC (2000). Moisture, protein, lipid, and ash were determined by using a hot air oven (Kendro M110, Germany), Kjeldahl apparatus (Buchi CH-9230, Switzerland), soxhlet apparatus (SRICO SMX 100) and muffle furnace (Cole-Parmer EW-33858-80, India), respectively.

Determination of FA content: TCA and Nash's Reagent preparation: $6 \%$ w/w TCA (Trichloroacetic acid) and Nash's reagent was prepared followed by Jaman et al. (2015).The verified fish samples are subjected to adjust the $\mathrm{pH}$ within a range from 6.0 to 6.5. For that, a $0.1 \mathrm{~N} \mathrm{KOH}$ and $0.1 \mathrm{~N} \mathrm{HCl}$ have been prepared. All reagents were stored in the dark-glass reagent bottle for all time to maintain its quality.

Fish sample preparation for determination of FA: FA content was determined by the spectrophotometric method. Fish samples were cut into small pieces under verification. Each of 
the fish samples weighted $30 \mathrm{~g}$ by electronic balance. Then fish flesh was taken into a blender and for homogenization, blended for $10 \mathrm{~min}$. Then a $60 \mathrm{ml}$ of $6 \% \mathrm{w} / \mathrm{w}$ TCA was added for extraction of FA from the fish flesh. Whatman number 1 filter paper was used to filter the extract solution to remove unwanted particles. Though the addition of TCA reduced the $\mathrm{pH}$ value of the sample, thus the $\mathrm{pH}$ was adjusted from 6.00 to 6.50 using $0.1 \mathrm{~N} \mathrm{KOH}$ and $0.1 \mathrm{~N}$ $\mathrm{HCl}$. From the $\mathrm{pH}$ adjusted extract, $5 \mathrm{ml}$ sample was taken in a $50 \mathrm{ml}$ volumetric flask and kept in a freeze at a normal temperature for $1 \mathrm{hr}$. After the stipulated time, the sample taking out, and $2 \mathrm{ml}$ Nash's reagent was added as an indicator. Then, the sample was heated at $60^{\circ} \mathrm{C}$ using a water bath for 30 mins. The absorbance of the sample in the cuvette was measured at $415 \mathrm{~nm}$ immediately by UV/Vis spectrophotometer. Triplicate absorbance was made for each sample and recorded for further calculation. Then the sample reading was placed in the standard curve for the calculation of the FA content of the sample. To study the effect of cooking on FA content, the frozen stored samples were further cooked at $100^{\circ} \mathrm{C}$ for 15 minute and determined the FA content following the same method.

Data analysis: Experiments were run in triplicates. Data were subjected to analysis of variance (ANOVA) and mean comparisons (T-test) were carried out by Duncan's multiple range test. The analysis was performed using the SPSS package (SPSS 16.00 for windows, SPSS Inc., Chicago, IL, USA) (Gomez and Gomez, 1984).

\section{Results and Discussion}

Proximate composition: The result of moisture, protein, lipid, and ash content of fresh and frozen stored samples from three different sources are shown in Table I. In fish samples from cultured source, fresh $P$. pangasius showed higher moisture content $(78.20 \%)$ which was reduced to $75.11 \%$ in the frozen stored sample. Similar moisture content was found between $G$. catla and $P$. pangasius $(p>0.05)$. A. testudineus showed lower moisture content in both fresh (75.81\%) and frozen stored (74.52\%) conditions compared to other fish from cultured pond source. Moisture content in river fishes, T. purava, $S$. panijus and $O$. pama were 75.69, 79.32, and $74.26 \%$ which significantly $(p<0.05)$ decreased to $73.72,77.26$ and $73.29 \%$, respectively at the end of the frozen storage period. Among the marine fish samples, fresh $R$. rita represents maximum moisture content $(75.87 \%)$ followed by $S$. longiceps $(73.78 \%)$ and $S$. orientalis (71.65\%). After the frozen storage period, moisture content was increased for $R$. rita, (76.18\%) while decreased for $S$. orientalis (70.69\%) and $S$. longiceps $(72.76 \%)$. Among all the species used in this experiment, the higher moisture content was found for $S$. panijus both fresh (79.32\%) and frozen storage $(77.26 \%)$ while the lower value for marine $S$. orientalis (from 71.65 to $70.69 \%$ ). Moisture content was found low for all species (except $R$. rita). The decrease in moisture content might due to sublimation of surface water of meat in the freezer (Mazrouh 2015).

Protein content in culture fish was ranged from 16.70 to $18.23 \%$ and 15.44 to $16.51 \%$ in fresh and frozen stored samples, respectively. Compare to other fish species from cultured source, fresh $A$. testudineus fish had significantly higher protein content $(18.23 \%)$ which was significantly decreased $(16.51 \%)$ after the frozen storage $(p<0.05)$. On the other hand, all three fish from the estuarine river source showed similar protein content $(p>0.05)$. In fresh 
condition, the protein content was $18.89,18.17$, and $18.07 \%$ for $T$. purava, $S$. panijus and $O$. pama and which was decreased to $17.82,16.99$ and $16.91 \%$, respectively $(p>0.05)$.

Among the marine fish, protein content was found higher in $S$. orientalis $(24.71 \%)$ followed by $S$. longiceps $(20.80 \%$ ) and $R$. rita $(16.75 \%$ ) which decreased to $22.53,20.06$, and $16.32 \%$, respectively, after the frozen storage period. When protein content was compared among all the species, $S$. orientalis showed significantly higher protein content $(24.71 \%)$ at fresh fish which significantly reduced to $22.53 \%$ at the end of frozen storage $(p<0.05)$. In general, lower protein content was observed in the frozen stored sample than the fresh sample. Irrespective sources of all fish samples resulted in lower protein content in frozen stored fish sample than fresh fish sample might due to leaching, drip loss, degradation and denaturation of protein during frozen storage. Temperature abuse during the frozen period of fish could affect the migration of water vapor from the product to the surface of the container (Emire and Gebremariam 2010) thus allow the lowering of protein content. Leaching of protein was a common phenomenon during the cold storage period (Gandotra et al. 2012, Aberoumand 2013). Slow freezing and freezing temperature were reported as two major factors for protein denaturation during the frozen time (Emire and Gebremariam 2010). The post rigor stage, fish undergo rapid protein degradationas a result of endogenous bacterial enzymatic activities. Protein degradation is correlated with the destruction of its secondary, tertiary and quaternary structures which ultimately convert the proteins to the simple polypeptide chains (Careche and Li-Chan 1997).

In the culture pond, the higher lipid content $(3.04 \%)$ was found for $P$. pangasius followed by $A$. testudineus $(2.24 \%)$, and a lower-valued was recorded for $G$. catla $(1.36 \%)$. After frozen storage, a significant increase in lipid content was found for $P$. pangasius (from $3.04 \%$ to $7.19 \%), A$. testudineus (from 2.24 to $3.22 \%)$, and $G$. catla $(1.36$ to $2.06 \%)(p<0.05)$. Estuarine river fish showed a similar result of lipid content both at fresh and frozen storage conditions $(p>0.05)$. Fish from marine sources showed that fresh $S$. orientalis fish had higher lipid content (7.48\%) than that of $S$. longiceps $(6.92 \%)$ and $R$. rita (4.81\%). After frozen storage, lipid content increased to $7.81 \%, 8.63 \%$ and $6.16 \%$ for $S$. orientalis, $S$. longiceps and $R$. rita, respectively $(p<0.05)$. Among all the species from different sources, fresh marine $S$. orientalis had higher lipid content $(7.48 \%)$ while marine $S$. longiceps showed higher lipid $(8.63 \%)$ at the end of frozen storage $(p<0.05)$. Variation in lipid between fresh and frozen stored different fish samples might due to different biochemical changes occurred during frozen storage.

In the cultured species, higher ash content was found for $P$. pangasius $(1.81 \%)$ and lowered value for $A$. testudineus $(0.96 \%)$. A significant difference in ash content was found for all cultured samples $(p<0.05)$. Further, the ash content of estuarine species was $1.44 \%, 1.74 \%$, and $0.99 \%$ for $T$. purava, $S$. panijus and $O$. pama, respectively $(p<0.05)$. A slight decreased in ash content was observed for estuarine species from fresh to frozen storage. On the contrary, the average ash content of fresh marine fish was from 1.14 to $1.85 \%$ and frozen stored was ranged from 1.03 to $1.18 \%$, respectively (Table I). Fresh $R$. rita had higher ash content (1.85\%) compared to other species from three separate water bodies while frozen $S$. panijus showed higher ash content $(1.57 \%)$ among all the frozen samples. Temperature in fluctuation during frozen storage resulting fluctuation of fish body temperature could cause moisture and ash content reduction during frozen storage. Gandotra et al. (2012) reported that during frozen 
MD. BOKTHIER RAHMAN et al.

Table I. Proximate composition (\% of wet basis) of fish from different sources under fresh and frozen stored condition

\begin{tabular}{|c|c|c|c|c|c|c|c|c|c|}
\hline \multirow{2}{*}{$\begin{array}{l}\text { Sources of } \\
\text { fish }\end{array}$} & \multirow{2}{*}{ Species } & \multicolumn{4}{|c|}{ Fresh } & \multicolumn{4}{|c|}{ Frozen stored (120 days) } \\
\hline & & Moisture & Protein & Lipid & Ash & Moisture & Protein & Lipid & Ash \\
\hline \multirow{3}{*}{$\begin{array}{l}\text { Culture } \\
\text { pond }\end{array}$} & Gibelion catla & $78.01 \pm 2.08^{\text {aAtu }}$ & $16.70 \pm 0.70^{\mathrm{bAx}}$ & $1.36 \pm 0.12^{\mathrm{cAy}}$ & $1.13 \pm 0.11^{\mathrm{bAvw}}$ & $75.12 \pm 1.06^{\mathrm{aAv}}$ & $15.44 \pm 0.69^{\mathrm{aAxw}}$ & $2.06 \pm 0.29^{\mathrm{cBz}}$ & $0.97 \pm 0.05^{\mathrm{aAv}}$ \\
\hline & $\begin{array}{l}\text { Pangasius } \\
\text { pangasius }\end{array}$ & $78.20 \pm 0.6^{\mathrm{baAt}}$ & $16.99 \pm 0.30^{\mathrm{bAx}}$ & $3.04 \pm 0.25^{\mathrm{aAw}}$ & $1.81 \pm 0.06^{\mathrm{aAt}}$ & $75.11 \pm 0.34^{\mathrm{aBv}}$ & $15.48 \pm 0.54^{\mathrm{aAxw}}$ & $7.19 \pm 0.28^{\mathrm{aBv}}$ & $1.01 \pm 0.03^{\mathrm{aBu}}$ \\
\hline & $\begin{array}{l}\text { Anabas } \\
\text { testudineus }\end{array}$ & $75.81 \pm 0.27^{\text {caAut }}$ & $18.23 \pm 0.47^{\mathrm{a} A v \mathrm{w}}$ & $2.24 \pm 0.30^{\mathrm{bAx}}$ & $0.96 \pm 0.04^{\mathrm{cAxw}}$ & $74.52 \pm 0.53^{\mathrm{aBvw}}$ & $16.51 \pm 0.50^{\mathrm{aBwx}}$ & $3.22 \pm 0.67^{\mathrm{bBxy}}$ & $1.15 \pm 0.12^{\mathrm{aBu}}$ \\
\hline \multirow{3}{*}{$\begin{array}{l}\text { Estuarine } \\
\text { river }\end{array}$} & Thryssa purava & $75.69 \pm 0.47^{\text {bAut }}$ & $18.89 \pm 0.18^{\mathrm{aAv}}$ & $2.86 \pm 0.11^{\mathrm{aAw}}$ & $1.44 \pm 0.03^{\mathrm{bAu}}$ & $73.72 \pm 0.27^{\mathrm{bBwv}}$ & $17.82 \pm 0.43^{\mathrm{aBv}}$ & $2.99 \pm 0.20^{\mathrm{bAxy}}$ & $1.15 \pm 0.05^{\mathrm{bBu}}$ \\
\hline & $\begin{array}{l}\text { Sillaginopsis } \\
\text { panijus }\end{array}$ & $79.32 \pm 0.68^{\mathrm{aAt}}$ & $18.17 \pm 0.67^{\mathrm{Aavw}}$ & $2.36 \pm 0.24^{\mathrm{cAx}}$ & $1.74 \pm 0.08^{\mathrm{aAt}}$ & $77.26 \pm 0.46^{\mathrm{aBt}}$ & $16.99 \pm 0.20^{\mathrm{bBw}}$ & $2.61 \pm 0.18^{\mathrm{bAyx}}$ & $1.57 \pm 0.10^{\mathrm{aAt}}$ \\
\hline & $\begin{array}{l}\text { Otolithoides } \\
\text { pama }\end{array}$ & $74.26 \pm 0.45^{\mathrm{cAv}}$ & $18.07 \pm 0.14^{\mathrm{bAwv}}$ & $3.32 \pm 0.11^{\mathrm{aAw}}$ & $0.99 \pm 0.04^{\text {cAwvx }}$ & $73.29 \pm 0.31^{\mathrm{bBw}}$ & $16.91 \pm 0.21^{\mathrm{bBw}}$ & $3.09 \pm 0.21^{\mathrm{aAx}}$ & $0.95 \pm 0.03^{\mathrm{cBv}}$ \\
\hline \multirow{3}{*}{ Marine } & Sarda orientalis & $71.65 \pm 0.36^{\mathrm{cAw}}$ & $24.71 \pm 0.06^{\mathrm{aAt}}$ & $7.48 \pm 0.27^{\mathrm{aAt}}$ & $1.14 \pm 0.03^{\mathrm{bAv}}$ & $70.69 \pm 0.07^{\mathrm{cBx}}$ & $22.53 \pm 0.10^{\mathrm{aBt}}$ & $7.81 \pm 0.12^{\mathrm{bAu}}$ & $1.03 \pm 0.06^{\mathrm{aBu}}$ \\
\hline & Rita rita & $75.87 \pm 1.04^{\text {aAut }}$ & $16.75 \pm 0.75^{\mathrm{cAx}}$ & $4.81 \pm 0.63^{\mathrm{cAv}}$ & $1.85 \pm 0.05^{\mathrm{aAt}}$ & $76.18 \pm 0.60^{\mathrm{aAu}}$ & $16.32 \pm 0.61^{\mathrm{cAxw}}$ & $6.16 \pm 0.42^{\mathrm{cBw}}$ & $1.26 \pm 0.17^{\mathrm{aBu}}$ \\
\hline & $\begin{array}{l}\text { Sardinella } \\
\text { longiceps }\end{array}$ & $73.78 \pm 0.27^{\mathrm{bAv}}$ & $20.80 \pm 0.51^{\mathrm{bAu}}$ & $6.92 \pm 0.20^{\mathrm{bAu}}$ & $1.22 \pm 0.13^{\mathrm{bAv}}$ & $72.76 \pm 0.83^{\mathrm{bBw}}$ & $20.06 \pm 0.12^{\mathrm{bBu}}$ & $8.63 \pm 0.18^{\mathrm{aBt}}$ & $1.18 \pm 0.13^{\mathrm{aAu}}$ \\
\hline
\end{tabular}

Means \pm standard deviation $(\mathrm{n}=3)$.
Different small alphabet $(\mathrm{a}-\mathrm{c})$ as superscript within the same column indicate a significant difference $(p<0.05)$ among the 3 species from the same source; different capital alphabet (A-B) as superscript within the same row indicate a significant difference $(p<0.05)$ between same constituent and same species; different small alphabet $(\mathrm{t}-\mathrm{z})$ as superscript within the same column indicate a significant difference $(p<0.05)$ among the 9 species from the 3 different sources. 
storage ash and moisture content decreased significantly. In general, during the frozen storage period, decreased moisture content upon frozen storage in all fish samples might due to dehydration and drip loss occurred in the fish sample. Further, an inverse relationship was found between the moisture, and lipid content. Thus, during frozen storage lipid content significantly increased with decreasing moisture, protein, and ash content. Similar results were also available in the literature (Emire and Gebremariam 2010, Beklevik et al. 2005). In general, the condition of fish at the time of frozen storage relates to the nutritional status or the stage of spawning that could affect both chemical compositions of frozen fish. The present result indicated that fish of marine sources represented higher protein (except $R$. rita), lipid and ash content followed by estuarine river, and culture pond fish species. Thus, the present findings indicated that proximate compositions of fish were varied widely based on species and location.

FA content: In fresh $G$. catla, the FA concentration was $0.63 \mu \mathrm{g} / \mathrm{g}$ and similar FA content was observed during 14 days frozen storage $(p>0.05)$. With increased frozen storage time, a significant higher FA content was 0.80 and $0.95 \mu \mathrm{g} / \mathrm{g}$ at 30 and 120 days storage time, respectively. In the case of $P$. pangasius, with increasing storage time significant increase in FA concentration was observed during the whole storage period $(p<0.05)$ (Table II). Furthermore, $A$. testudineus showed non-significant differences in FA content $(0.71-0.76 \mu \mathrm{g} / \mathrm{g})$ from 0 to 14 days of frozen storage time $(p>0.05)$. After 30 and 120 days of frozen storage period, the FA were 0.99 and $1.53 \mu \mathrm{g} / \mathrm{g}$, respectively $(p<0.05)$. Among the three species, in fresh condition, $P$. pangasius had the lowest and $A$. testudineus had the highest FA content $(p<0.05)$. But, with increased frozen storage time from 7 to 120 days, $P$. pangasius revealed the highest $(2.11 \mu \mathrm{g} / \mathrm{g})$ and $G$. catla lowest $(0.95 \mu \mathrm{g} / \mathrm{g})$ FA content $(p<0.05)$. Among the three species, $G$. catla represented lower FA content compared to other fish species at any day storage time (Table II).

Table II. FA content in fish from different sources during frozen storage conditions

\begin{tabular}{|c|c|c|c|c|c|c|}
\hline \multirow{2}{*}{$\begin{array}{l}\text { Sources } \\
\text { of fish }\end{array}$} & \multirow{2}{*}{ Fish species } & \multicolumn{5}{|c|}{$\mathrm{FA}(\mu \mathrm{g} / \mathrm{g})$} \\
\hline & & 0 day & 7 days & 14 days & 30 days & 120 days \\
\hline \multirow{3}{*}{$\begin{array}{l}\text { Culture } \\
\text { pond }\end{array}$} & Gibelion catla & $0.63 \pm 0.02^{\mathrm{cBx}}$ & $0.66 \pm 0.05^{\mathrm{cBx}}$ & $0.64 \pm 0.05^{\mathrm{cBy}}$ & $0.80 \pm 0.08^{\mathrm{bCx}}$ & $0.95 \pm 0.02^{\mathrm{aCy}}$ \\
\hline & $\begin{array}{l}\text { Pangasius } \\
\text { pangasius }\end{array}$ & $0.41 \pm 0.02^{\mathrm{eCz}}$ & $0.47 \pm 0.03^{\mathrm{dCy}}$ & $0.61 \pm 0.04^{\mathrm{cBy}}$ & $1.95 \pm 0.06^{\mathrm{bAv}}$ & $2.11 \pm 0.15^{\mathrm{aAw}}$ \\
\hline & $\begin{array}{l}\text { Anabas } \\
\text { testudineus }\end{array}$ & $0.71 \pm 0.01^{\mathrm{cAw}}$ & $0.74 \pm 0.03^{\mathrm{cAw}}$ & $0.76 \pm 0.04^{\mathrm{cAx}}$ & $0.99 \pm 0.05^{\mathrm{bBw}}$ & $1.53 \pm 0.12^{\mathrm{aBx}}$ \\
\hline \multirow{3}{*}{$\begin{array}{l}\text { Estuarine } \\
\text { river }\end{array}$} & Thryssa purava & $0.51 \pm 0.03^{\mathrm{cBy}}$ & $0.67 \pm 0.06^{\mathrm{bBxw}}$ & $0.66 \pm 0.06^{\mathrm{bBy}}$ & $0.76 \pm 0.10^{\mathrm{bCx}}$ & $1.74 \pm 0.05^{\mathrm{aAw}}$ \\
\hline & $\begin{array}{l}\text { Sillaginopsis } \\
\text { panijus }\end{array}$ & $0.89 \pm 0.01^{\mathrm{cAv}}$ & $0.96 \pm 0.05^{\mathrm{bAv}}$ & $1.15 \pm 0.13^{\mathrm{bAw}}$ & $1.07 \pm 0.09^{\mathrm{bBw}}$ & $1.94 \pm 0.13^{\mathrm{aAw}}$ \\
\hline & $\begin{array}{l}\text { Otolithoides } \\
\text { pama }\end{array}$ & $0.53 \pm 0.01^{\mathrm{dBy}}$ & $0.76 \pm 0.06^{\mathrm{cBxw}}$ & $1.12 \pm 0.11^{\mathrm{bAw}}$ & $1.83 \pm 0.10^{\mathrm{aAv}}$ & $1.95 \pm 0.11^{\mathrm{aAw}}$ \\
\hline \multirow{3}{*}{ Marine } & Sarda orientalis & $1.69 \pm 0.01^{\mathrm{eAt}}$ & $1.99 \pm 0.07^{\mathrm{dAt}}$ & $2.36 \pm 0.08^{\mathrm{cCv}}$ & $3.27 \pm 0.08^{\mathrm{bAt}}$ & $5.20 \pm 0.09^{\mathrm{aAt}}$ \\
\hline & Rita rita & $0.73 \pm 0.02^{\mathrm{eCw}}$ & $0.95 \pm 0.02^{\mathrm{dCv}}$ & $2.62 \pm 0.06^{\mathrm{cAt}}$ & $2.93 \pm 0.05^{\mathrm{bBu}}$ & $3.22 \pm 0.08^{\mathrm{aCv}}$ \\
\hline & $\begin{array}{l}\text { Sardinella } \\
\text { longiceps }\end{array}$ & $1.65 \pm 0.02^{\mathrm{dBu}}$ & $1.72 \pm 0.05^{\mathrm{dBu}}$ & $2.49 \pm 0.05^{\mathrm{cBu}}$ & $3.02 \pm 0.05^{\mathrm{bBu}}$ & $3.96 \pm 0.11^{\mathrm{aBu}}$ \\
\hline
\end{tabular}

Means \pm standard deviation $(n=3)$; Different small alphabet $(a-c)$ in the same row represent the significant difference $(p<0.05)$ in FA content in same species; different capital alphabet in the same column represent the significant difference $(p<0.05)$ in FA content in 3 different fish species from the same source; different small alphabet $(\mathrm{t}-\mathrm{z})$ as superscript within the same column indicate significant differences among the 9 species from the 3 different sources $(p<0.05)$. 0, 7, 14, 30, and 120 are indicating freezing day $(\mathrm{s})$. 
Hoque et al. (2016) and Jaman et al. (2015) reported that cultured samples had a small quantity of naturally occurring FA in their muscle having values ranging from 1.45 to $2.60 \mu \mathrm{g} / \mathrm{g}$.

In $T$. purava, FA content was $0.57,0.67,0.66,0.76$ and $1.74 \mu \mathrm{g} / \mathrm{g}$ at $0,7,14,30$ and 120 days frozen storage time, respectively. Lower and higher FA content was found in fresh and 120 days of storage fish, respectively. During frozen storage time at 7, 14, and 30 days nonsignificant differences in FA contents was found for $T$. purava $(p>0.05)$. On the other hand, the FA content was $0.89 \mu \mathrm{g} / \mathrm{g}$ in fresh $S$. panijus. FA contents were found as increasing trends from days 7 to days 120 which ranged from 0.96 to $1.94 \mu \mathrm{g} / \mathrm{g}$, respectively. Non-significant difference in FA contents were observed at 7, 14 and 30 days storage time $(p>0.05)$. On the other hand, the lower and higher values for FA content were 0.53 and $1.95 \mu \mathrm{g} / \mathrm{g}$ in $O$. pama, which was calculated during fresh ( 0 day) and 120 days of storage conditions, respectively. With increasing frozen storage time from days 7 to 120 days, FA content was increased $(p<0.05)$. Nonsignificant differences in FA contents were found at 30 and 120 days storage time $(p>0.05)$. Among the three estuarine river fish samples, T. purava had lower FA content followed by $O$. pama and $S$. panijus. At the end of the storage period (120 days), the non-significant difference in FA content was found among fish samples $(p>0.05)$ which was significantly higher than the value at 0 day $(p<0.05)$ (Table II). Xu and Rogers (1995) found $0.563 \mu \mathrm{g} / \mathrm{g}$ of FA for river catfish at the fresh conditions which also a similar result of the present study. FA content in three marine water fish species under fresh and frozen storage conditions is also determined (Table II). The result revealed that with the increasing storage time from 0 to 120 days, asignificant increase of FA content was found for both $S$. orientalis and $R$. rita $(p<0.05)$. Compared among three marine fish species, $S$. orientalis had higher FA content both at fresh $(0$ day) and after frozen storage time (120 days) which valued $1.69 \mu \mathrm{g} / \mathrm{g}$ and $5.20 \mu \mathrm{g} / \mathrm{g}$, respectively. However, at the same storage time (0 day and 120 days) $R$. rita had the lowest FA content $(0.73$ and $3.22 \mu \mathrm{g} / \mathrm{g})$ than other marine fish species. Another marine sample like R.rita had FA content $0.73 \mu \mathrm{g} / \mathrm{g}$ at initial period. $S$. longiceps had a FA content $1.65,1.72,2.49,3.02$, and $3.96 \mu \mathrm{g} / \mathrm{g}$ at $0,7,14,30$, and 120 days frozen storage period, respectively. $S$. longiceps showed a non-significant difference in FA content between 0 day (fresh) and 7 days frozen storage $(p>0.05)$. In general, $S$. orientalis had higher FA content both in fresh and end of frozen storage period followed by $S$. longiceps and R.rita. Frozen marine fish had higher natural FA in their muscle (ranged from 1.55 to $3.90 \mu \mathrm{g} / \mathrm{g}$ ) (Jaman et al. 2015) which supports the present results.

In general, the present result revealed that FA content in fish varies from species to species, location to location, under storage condition, and most importantly based on red muscle content as well (Hoque et al. 2018). The variation of FA contents observed in present study among the fish samples could be described based on TMAO content. TMAO content has a direct link with red muscle i.e., higher red muscle fish have higher TMAO content. Marine fish have a higher level of TMAO content due to the presence of red muscle (Tsuda et al. 1988, Jiang et al. 2006, Jaman et al. 2015) which is a similar result of the present study (Fig. 1). During frozen storage of fish at low temperatures (below 0), TMAO content is increased with increasing frozen storage time. Bianchi et al. (2007) reported that the FA content increased to $134 \%$ after 6 days of icing, thus confirm the production of FA compound at temperatures around $0^{\circ} \mathrm{C}$. After 3 months of home-frozen, the FA content of Mullet was $3.38 \mu \mathrm{g} / \mathrm{g}$ and after 4 months, the FA of Mackerel was $2.6 \mu \mathrm{g} / \mathrm{g}$ (Bianchi et al. 2007) which support the present results. Xu and Rogers (1995) 
documented that the endogenous FA of several fish species was ranged from 01-31.8 $\mu \mathrm{g} / \mathrm{g}$. FA content in fresh marine samples was in the range of 0.38 to $15.75 \mu \mathrm{g} / \mathrm{g}$ (Noordiana et al. 2011).

Effects of cooking on FA content: In Bangladesh, fish are generally eaten after cooking, thus all the samples were also analyzed just after boiling to evaluate the effect of cooking on the FA content of frozen fish (120 days frozen stored samples). The result revealed that after cooking, FA content was decreased for all fish samples to a great extent irrespective of sources. Among the culture pond fish samples, after cooking $P$. pangasius had a significant reduction in FA (from 2.11 to $0.03 \mu \mathrm{g} / \mathrm{g}$ ) (Fig. 2). A . testudineus had higher FA $(0.38 \mu \mathrm{g} / \mathrm{g})$ under cooking conditions compare to other species from the same sources. On the other hand, FA content of estuarine river water fish samples showed a significant reduction when comparing 120 days of frozen samples before and after cooking. At 120 days, FA content in frozen $T$. purava, $S$. panijus and $O$. pama were $1.74,1.94$, and $1.95 \mu \mathrm{g} / \mathrm{g}$ which reduced to $0.59,0.49$ and $0.52 \mu \mathrm{g} / \mathrm{g}$, respectively after cooking $(p<0.05)$. Further, marine water fish samples also had a similar trend to reduce FA content under cooking conditions.

After frozen cooked, $R$. rita showed a lower value of FA content $(0.22 \mu \mathrm{g} / \mathrm{g})$ in comparison with other species from the same source (Fig. 2).

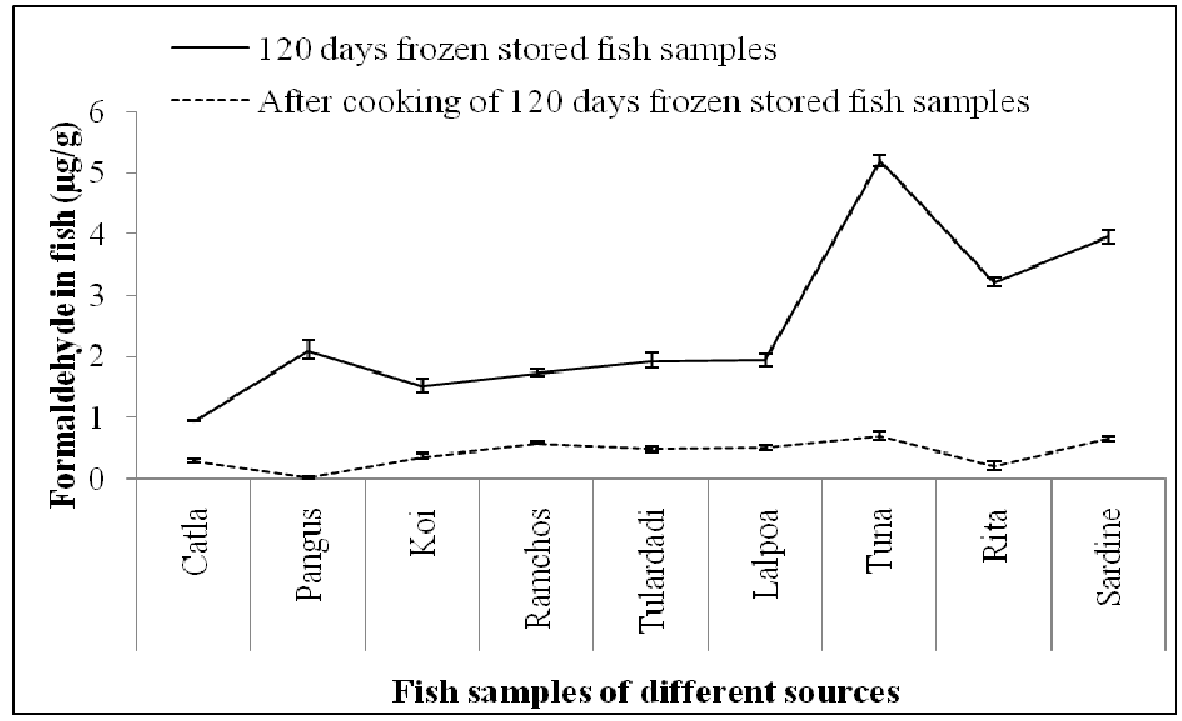

Fig. 2. Comparison of FA content in frozen and cooked fish samples after 120 days storage period (straight line indicates frozen fishes and dotted line indicates cooked samples after 120 days of storage time).

In general, frozen storage of fish caused for an increase in FA content significantly (Table II) which further decreased due to cooking. The present findings were similar to the study of Hoque et al. (2016). Bianchi et al. (2007) also reported a decrease in the FA content from 10.3 $\mu \mathrm{g} / \mathrm{g}$ to $7.1 \mu \mathrm{g} / \mathrm{g}$ for roasting of $S$. longiceps fish. The same study also found reduced FA content in cod and hakes due to boiling and roasting. All frozen stored fish samples in this experiment contained much higher FA content compared with the recommended value set by the United States Environmental Protection Agency $(0.2 \mu \mathrm{g} / \mathrm{g})$ and WHO $(0.15 \mu \mathrm{g} / \mathrm{g})$ (Zhang et al. 
2015). However, fresh and frozen stored cooked fish samples had slightly higher FA content than the recommended value. These elevated concentrations of FA in fishes may be antigenic and toxic or fatal to consumers (Wooster et al. 2005). Therefore, the study recommended that fresh i.e., minimum frozen storage duration and properly cooked fish could minimize the public health risk caused by hazardous chemicals like FA formed in fish.

The quality aspects (proximate composition and FA content) of fish from three different sources were analyzed under fresh and frozen stored condition. Losses of protein and moisture content during frozen storage were common scenarios for all the fish species studied here due to dehydration, drip loss, and denaturation of the protein. In fresh samples, marine fish showed higher FA content compare to estuarine river and cultured samples. The experiment also proved that among the frozen samples, a significant increase in FA content was found for all samples and the evidence was most prominent in marine fish species. However, the cooking process could decrease the FA content to some extent irrespective of fish species and sources. In conclusion, frozen storage of fish could alter the nutritional properties and increased health hazardous chemicals especially FA which could be highly concern in terms of food safety aspects.

Acknowledgments: The authors would like to thank the Chairman (Dr. Md. Munir Hossain) of the Department of Animal Breeding and Genetics, Bangladesh Agricultural University to help during the determination of the proximate composition of fish. This study was supported by the National Science and Technology (NST) fellowship under the Ministry of Science and Technology, Government of the People's Republic of Bangladesh.

\section{Literature Cited}

Aberoumand, A., 2013. Impact of freezing on nutritional composition of some less known selected fresh fishes in Iran. Int. Food Res. J., 20(1):347-350.

Adel, A. El. L., I. K. Khalil, A. El. S. Shaban, R. M. Hassan, A. M. Awad, and M.H., Roby, 2019. Changes in Proximate Composition of Mullet Fish Steaks During Frozen Storage and Cooking Techniques. Scho J Food \& Nutr., 1(5): DOI: 10.32474/SJFN.2019.01.000125

Ahmed, Z.A.M., M.I. Dosoki, and S.A.A, Nasr, 2012. Review Article: occupational hazards in fish industry. World J. Fish Mar. Sci., 4(2): 201-210.

Beklevik, G., A. Polat and F. Ozogul, 2005. Nutritional value of seabass (Dicentrarchus labrax) fillets during frozen (-18C) storage. Turk. J. Vet. Anim. Sci., 29: 891-895.

Benjakul, S., W. Visessanguan and J. Tueksuban, 2003. Changes in physico-chemical properties and gel-forming ability of lizardfish (Saurida tumbil) during post- mortem storage in ice. Food Chem., 80: 535-544.

Bianchi, F., M. Careri, M. Musci and A. Mangia, 2007. Fish and food safety, determination of formaldehyde in 12 fish species by SPME extraction and GC-MS analysis. Food Chem., 100: 1049-1053.

Careche, M. and E.C.Y. Li-Chan, 1997. Structural changes in cod myosin after modification with formaldehyde or frozen storage. J. Food Sci, 62: 717-723.

Chiou, J., A.H.H. Leung, H.W. Lee and W.T. Wong, 2015. Food Safety Special Issue: Rapid testing methods for food contaminants and toxicants. J. Integr. Agric., 14 (11): 2243-2264.

Emire, S.A. and M.M. Gebremariam, 2010. Influence of frozen period on the proximate composition and microbiological quality of Nile tilapia. J. Food Proc. Preser., 34:743-757. 
Erondu, E.S. and P.E. Anyanwu, 2005. Potential hazards and risks associated with the aquaculture industry. Afr. J. Biotechnol., 4(13): 1622-1627.

Gandotra, R., S. Sharma, M. Koul, S. Gupta, 2012. Effect of chilling and freezing on fish muscle. IOSR J. Pharm., 2(5): 5-9.

Gomez, K.A. and A.A. Gomez, 1984. Statistical procedures for agricultural research (2nd Ed.). John Wiley and Sons, New York, $680 \mathrm{p}$.

Handford, C.E., K. Campbell and C.T. Elliott, 2016. Impacts of milk fraud on food safety and nutrition. Compr. Rev. Food Sci. Food Safe.., 15: 130-141.

Hoque, M.S., L. Jacxsens, B.D. Meulenaer and A.K.M.N. Alam, 2016. Quantitative risk assessment for formalin treatment in fish preservation: food safety concern in local market of Bangladesh. Proced. Food Sci., 6: 151-158.

Hoque, M.S., L. Jacxsens, M.B. Rahman, A.K.M.N. Alam, S.M.O. Azad, B.D. Meulenaer, C. Lachat and M. Rahman, 2018. Evaluation of artificially contaminated fish with formaldehyde under laboratory conditions and exposure assessment in freshwater fish in Southern Bangladesh. Chemosphere, 195: 702-712.

Hoque, M.Z., M.S. Islam, M.I. Khalil, and M.R. Bari, 2016. Formalin treated fish marketing and its impact on public health. Int. J. Acad. Res., 1(1): 7-12.

Jaman, N., M.S. Hoque, S.C. Chakraborty, M.E. Hoq and H.P. Seal, 2015. Determination of formaldehyde content by spectrophotometric method in some freshwater and marine fishes of Bangladesh. Int. J. Fish. Aquat. Stud., 2(6): 94-98.

Jiang, S., L. Yu., S. Leng, Y. Zhang, J. Cheng and Y. Dai, 2006. Association between XRCC1 gene polymorphisms and DNA damage of workers exposed to formaldehyde. Wei Sheng Yan Jiu., 35(6): 675-687.

Mahboob, S., K.A. Al-Ghanim, H.F. Alkahem Al-Balawi, F. Al-Misned and Z. Ahmed, 2019. Study on assessment of proximate composition and meat quality of fresh and stored Clarias gariepinus and Cyprinus carpioS.Braz. J. Biol., 79(4): 651-658.

Mazrouh, M.M., 2015. Effects of freezing storage on the biochemical composition in muscles of Saurida undosquamis comparing with imported frozen. Int. J. Fish. Aquat. Stud., 3(2):

Noordiana, N., A.B. Fatimah and Y.C.B. Farhana, 2011. Formaldehyde content and quality characteristics of fish and seafood from wet markets. Int. Food Res. J., 18: 125-136.

Norliana, S., A.S. Abdulamir, F.A. Bakar and A.B. Salleh, 2009. The health risk of formaldehyde to human beings. Am J Pharmacol Toxicol., 4(3): 98-106.

Sotelo, C.G., C. Piñeiro and R.I. Pérez-Martín, 1995. Denaturation of fish protein during frozen storage: role of formaldehyde. Z Lebensm Unters Forch, 200:14-23.

Tsuda, M., N. Frank, S. Sato and T. Sugimura, 1988. Marked increase in the urinary level of $\mathrm{N}$-nitrosothioproline after ingestion of cod with vegetables. Cancer Res., 48(14): 4049-52.

Wooster, G.A., C.M. Martinez, P.R. Bowser, 2005. Human health risks associated with formalin treatments used in Aquaculture: Initial Study. N. Am. J. Aquac., 67: 111-113.

$\mathrm{Xu}, \mathrm{D}$. and A. Rogers, 1995. Formaldehyde residue in the muscle of Nile tilapia. Asian Fish. Sci., 8: 81-88.

Zhang, X., Y. Hui, Y. Cai and D. Huang, 2015. The research progress of endogenous formaldehyde in aquatic products. World J. Eng. Technol., 3: 272-276. 